\title{
Water Application Scheduling by Pan Evaporation for Drip-irrigated Tomato
}

\author{
Salvadore J. Locascio ${ }^{1}$ and Allen G. Smajstrla ${ }^{2}$ \\ Institute of Food and Agricultural Sciences, University of Florida, Gainesville, FL 32611 \\ Additional index words. micro-irrigation, tensiometer, Lycopersicon esculentum
}

\begin{abstract}
Tomatoes (Lycopersicon esculentum Mill.) were grown on an Arredondo fine sandy soil to evaluate the effects of water quantity applied by drip irrigation scheduled by pan evaporation in a 3-year study. Water was applied to polyethylene-mulched tomatoes at $0,0.25,0.50,0.75$, and 1.0 times pan evaporation in one application per day. Irrigation was also scheduled with tensiometers to apply water to maintain soil water tension above $10 \mathrm{cb}$. The response to irrigation varied with rainfall during the three seasons. In an extremely dry season, fruit yields were doubled by irrigation. Total fruit yields were highest with irrigation quantities of 0.75 and 1.0 times pan and significantly lower with 0.25 and 0.50 times pan. In an extremely wet season, fruit yields were not influenced by water quantities from $O$ to 1.0 times pan. In a third season that was wet from the middle to the end of the season, irrigation more than doubled the marketable fruit yield. However, with an increase in water quantity from 0.25 to 0.75 times pan, yield increased only from 65.9 to 74.1 tha ${ }^{-1}$. Water uses during the three seasons with 0.75 pan were $31.8,31.1$, and $29.6 \mathrm{~cm}$, respectively. Fruit yields were similar with the 0.75-pan and 10-cb tensiometer treatments, but water uses with the latter treatment were 15.8, 17.0 , and $18.4 \mathrm{~cm}$ during the three seasons, respectively. Tomato leaf $N$ concentrations were reduced slightly with each increase in water quantity applied, even though $\mathrm{N}$ was applied with drip irrigation. Leaf $\mathrm{N}$ concentrations with the 10-cb treatment were generally equal to or higher than the concentrations with 0.75 pan.
\end{abstract}

Tomatoes grown for the fresh market in the southeastern United States are generally grown from transplants and on polyethylenemulched beds. Irrigation must be applied to minimize water stress and obtain maximum production of high fruit quality. In the past, water was applied as subsurface or overhead irrigation, with 115 to $150 \mathrm{~cm}$ or 38 to $50 \mathrm{~cm}$ per season, respectively (Locascio et al., 1982). Locascio and Myers ( 1974) found that one-half as much water was required with drip irrigation to produce similar tomato yields as with sprinkler irrigation providing that part of the $\mathrm{N}$ and $\mathrm{K}$ were injected with the irrigation water. Timing of fertilizer application was critical to obtain optimum tomato yields (Dangler and Locascio. 1990; Locascio et al., 1989). Part of the N-K must be applied preplant and part with drip irrigation to obtain maximum production on coarse-textured soils, as soluble nutrients are easily leached by drip irrigation (Goldberg et al., 1971; Persaud et al., 1976).

Scheduling water application is also critical, as excessive irrigation reduces yield (Locascio et al., 1989), while inadequate irrigation causes water stress and reduces production. In past studies on a coarse-textured soil, tomato water requirements were found to be above 0.5 times pan evaporation (Locascio and Smajstrla, 1989) and below 1.0 pan (Locascio et al., 1989). On finer-textured soils, water requirements were about 0.75 pan for a spring crop (Locascio et al., 1989) and 0.50 pan for a fall crop (Olson and Rhoads, 1992).

The adoption of drip irrigation by commercial tomato producers has been slow due to the increased management required and the increased cost compared to sprinkler or subsurface irrigation (Prevatt et al., 1984). As the need to conserve water increases due to urbanization, producer interest in drip irrigation has increased.

Received for publication 1 I May 1995. Accepted for publication 19 Sept. 1995. Florida Agricultural Experiment Sta2tion Journal series no. R-04529. Trade names are for information only and do not imply endorsement by the authors or the Univ. of Florida. The cost of publishing this paper was defrayed in part by the payment of page charges. Under postal regulations, this paper therefore must be hereby marked advertisement solely to indicate this fact.

'Horticultural Sciences Dept.

'Agricultural Engineering Dept.
Currently, about 4700 ha of tomatoes are drip irrigated in Florida (Hochmuth et al., 1993), and drip irrigation of tomato and other vegetables is increasing. A simple method to determine how much water to apply is of major concern. Applying water by drip irrigation in relation to the amount of water evaporated from a U.S. Weather Service Class A pan would be a convenient method to schedule irrigation, as these pan evaporation data are generally available in most farming areas. Studies were conducted to evaluate the effect of water quantity as a factor of pan evaporation on tomato production and leaf $\mathrm{N}$ concentration.

\section{Materials and Methods}

Studies were conducted during Spring 1990, 1991, and 1992 at the Horticultural Unit near Gainesville. Tomatoes were grown on an Arredondo fine sand (loamy, siliceous, hyperthermic, Grossarenic Paleudults) that had been previously cropped. After the application of $1.7 \mathrm{t} \cdot \mathrm{ha}^{-1} \mathrm{CaCO}_{3}$, the soil $\mathrm{pH}$ values ranged from 6.7 to 7.1 and Mehlich 1 extractable nutrients ranged as follows: 678 to $752 \mathrm{mg} \cdot \mathrm{kg}^{-1} \mathrm{Ca}, 72$ to $120 \mathrm{mg} \cdot \mathrm{kg}^{-1} \mathrm{Mg}$ (high level), 35 to 72 $\mathrm{mg} \cdot \mathrm{kg}^{-1} \mathrm{~K}$ (medium level), and 88 to $121 \mathrm{mg} \cdot \mathrm{kg}^{-1} \mathrm{P}$ (very high level). Treatments were five water quantities applied at $0,0.25$, $0.50,0.75$, and 1.0 times pan evaporation. In one additional treatment, irrigation was scheduled to maintain soil water tension below $10 \mathrm{cb}$ with tensiometers. Treatments were arranged in a randomized complete-block design and were replicated four times in single-row plots $1.83 \mathrm{~m}$ wide and $8.5 \mathrm{~m}$ long.

The soil was disced and beds $1.83 \mathrm{~m}$ apart with $0.6-\mathrm{m}$ bed tops were formed. Fertilizer was applied broadcast on the bed tops at 90N-P45-K108 $\mathrm{kg} \cdot \mathrm{ha}^{-1}$ plus $45 \mathrm{~kg} \cdot \mathrm{ha}^{-1}$ micronutrient mix and incorporated into the bed for all treatments. This was equivalent to $40 \%$ of the $\mathrm{N}$ and $\mathrm{K}$ and $100 \%$ of the P applied. Double-wall drip tubing (Chapin Twinwall, Watertown, N. Y.) with emitters spaced $30.5 \mathrm{~cm}$ apart and a delivery rate of $62 \mathrm{ml} \cdot \mathrm{m}^{-1} \cdot \mathrm{min}^{-1}$ was placed 7.5 to $10 \mathrm{~cm}$ from the bed center. Beds were fumigated with 390 $\mathrm{kg} \cdot \mathrm{ha}^{-1} 67 \%$. methyl bromide, and $33 \%$ chloropicrin mixture, and $0.038 \mathrm{~mm}$ thick black polyethylene mulch was applied over the bed. 
'Sunny' tomatoes were transplanted $0.5 \mathrm{~m}$ apart on the beds on 15 Mar. 1990, 2 Apr. 1991, and 26 Mar. 1992. Irrigation water quantities for the pan treatments were calculated based on the total plot area using the sum of previous 7 days pan evaporation and were applied daily. For the 10 -cb treatment, water was applied at 0.50 pan each time the soil water tension reached $10 \mathrm{cb}$. Two tensiometers were placed in each plot in the bed center in between plants at $15 \mathrm{~cm}$ deep. The $(10 \mathrm{cb})$ system was designed so that water could be applied as frequently as twice daily. For all treatments except the 0 -irrigation treatments, $60 \%$ of the total $\mathrm{N}$ and $\mathrm{K}$ or $13.4 \mathrm{~N}-0 \mathrm{P}-15.7 \mathrm{~K} \mathrm{~kg} \cdot \mathrm{ha}^{-1}$ fertilizer was injected once weekly for 10 applications, with the irrigation water. For the 0-irrigation treatments in 1990, the $40 \% \mathrm{~N}$ and $\mathrm{K}$ fertilizer was applied preplant with no additional fertilizer. In 1991 and 1992, in addition. the 60\% of the $\mathrm{N}$ and $\mathrm{K}$ was applied in 10 weekly applications each with $<0.1$ pan. Nutrient sources were ammonium nitrate, concentrated superphosphate, potassium chloride, and micronutrient mix (FN503, Frit Industries, Ozark, Ala.). Tomatoes were pruned by removing two lateral branches and staked 2 weeks after transplanting. insecticides and fungicides were applied as needed.

Recently matured whole leaves were sampled for $\mathrm{N}$ analysis by total Kjeldahl on 1 May, 1 June, and 22 June 1990; 17 May, 2 June, and 28 June 1991; and 1 May, 1 June, and 1 July 1992. Soil samples were taken from the bed center to a depth of $15 \mathrm{~cm}$ and analyzed for $\mathrm{NH}_{4}-\mathrm{N}$ and $\mathrm{NO}_{3}-\mathrm{N}$ on the above dates. Mature green fruit and riper fruit were harvested on 13 and 21 June 1990; 17 and 27 June 1991; and 15, 19, and 26 June 1992. Fruit were graded by size into extra-large, large, and medium marketable fruit by U.S. grade standards. Data were analyzed by an analysis of variance and mean separation was by orthogonal comparison.

\section{Results and Discussion}

Rainfall patterns during the three seasons were quite variable (Table 1). Spring 1990 was extremely dry. Except for 1 week during the 16 to $30 \mathrm{Apr}$. period when $8.4 \mathrm{~cm}$ of rain was recorded, rainfall averaged only about $1.5 \mathrm{~cm} /$ week from 16 Mar. through 15 May. Pan evaporation (Epan) during the entire season exceeded rainfall in all 15-day periods except the 16 to $30 \mathrm{Apr}$. period. The amount of water applied with the 1.0-pan treatment totaled $42.4 \mathrm{~cm}$ during the season. With the 10-cb treatment, water use was only $15.8 \mathrm{~cm}$ or about 0.37 times Epan. Rainfall during 1991 was relatively heavy and well-distributed throughout the season. In contrast, 1992 was very dry, with only the 16 to 30 Apr. period exceeding $5 \mathrm{~cm}$ when $10.4 \mathrm{~cm}$ of rain was recorded.

The effects of applied water quantity on the yield of extra-large, large, medium, and total marketable fruit yields varied with season (Table 2). During the very dry 1990 season, plant growth was poor with the application of no water, and yield of marketable fruit was low (30.7 th $\left.\mathrm{ha}^{-1}\right)$. More than one-half of this fruit was in the medium size category. With the application of 0.25 pan, the yield of extra-large fruit increased about three times and yield of large fruit was double that obtained with no irrigation. With an increase in water quantity from 0.25 to 0.75 pan, the yield of extra-large fruit increased to $36.5 \mathrm{t} \cdot \mathrm{ha}^{-1}$. With a further increase in water quantity to 1.0 pan, extra-large fruit yield dropped to $35.1 \mathrm{t} \cdot \mathrm{ha}^{-1}$. However, the marketable yield of large, medium. and total fruit increased linearly with increases in water quantity from 0.25 to 1.0 pan. Total fruit yield increased from $48.6 \mathrm{t} \cdot \mathrm{ha}^{-1}$ with 0.25 pan to $87.0 \mathrm{t} \cdot \mathrm{ha}^{-1}$ with 1.0 pan. With the 10 -cb treatment, total fruit yield was 84.0 $\mathrm{t} \cdot \mathrm{ha}^{-1}$. Water use of tomatoes with the latter treatment was only $35 \%$ of that used with the 1.0-pan treatment (Locascio and Smajstrla, 1993).
During the 1991 season, when rainfall averaged $3.4 \mathrm{~cm}$ per week, yields of extra-large, large, and total marketable fruit were not affected by applying water. During the very dry 1992 season, fruit yields in all size categories were significantly increased by water application. The largest yield increase occurred in the extralarge fruit category (11 3\% higher yield with irrigation compared to the yield with no irrigation). The increase in yield of medium size fruit with irrigation was $23 \%$. Irrigation water quantity significantly increased the yield of extra-large fruit and the total marketable fruit yields in a quadratic fashion. The highest yield of extralarge fruit was obtained with 0.50 pan and the highest total marketable yield was obtained with 0.75 pan. Fruit yields of all fruit sizes were similar with water scheduled with a tensiometer to maintain the soil at $10 \mathrm{cb}$ and water applied at 0.75 pan. Total irrigation water use with the former treatment was only $55 \%$ of that with the latter treatment. In earlier similar work, water requirements were $>0.5$ pan (Locascio and Smajstrla, 1989) and between 0.5 pan and 1.0 pan (Locascio et al., 1989). Similar savings in water with tensiometer scheduled irrigations of tomato were also shown earlier (Smajstrla and Locascio, 1990).

In 1990 , leaf tissue $\mathrm{N}$ concentrations were $>70 \mathrm{~g} \cdot \mathrm{kg}^{-1}$ (Fig. 1) with all treatments at the 1 May sampling and were not consistently influenced by water quantity applied. At the 1 June sampling, leaf $\mathrm{N}$ concentrations were lower with 0 than 0.25 pan. These $\mathrm{N}$ concentrations reflect that only preplant $\mathrm{N}$ and no fertigated $\mathrm{N}$ was applied with the 0 -water treatment. With an increase in water quantity from 0.25 to 1.0 pan, leaf $\mathrm{N}$ was reduced from 53 to 43

Table 1. Rainfall and irrigation during biweekly periods during the 1990 to 1992 tomato seasons with 1.0 pan and $10 \mathrm{cb}$ water application treatments.

\begin{tabular}{|c|c|c|c|}
\hline \multirow{2}{*}{$\begin{array}{l}\text { Time } \\
\text { period }\end{array}$} & \multirow{2}{*}{$\begin{array}{l}\text { Rainfall } \\
\qquad(\mathrm{cm})\end{array}$} & \multicolumn{2}{|c|}{ Irrigation quantity $(\mathrm{cm})$} \\
\hline & & 1.0 pan & $10 \mathrm{cb}$ \\
\hline \multicolumn{4}{|c|}{1990} \\
\hline 16-3 Mar. & 4.6 & 2.5 & 1.8 \\
\hline 1-15 Apr. & 4.1 & 5.0 & 0.8 \\
\hline 16-30 Apr. & 8.4 & 4.3 & 0.5 \\
\hline 1-15 May & 2.0 & 13.0 & 2.1 \\
\hline 16-31 Маy & 6.6 & 9.6 & 5.0 \\
\hline 1-15 June & 7.4 & 5.1 & 3.2 \\
\hline 16-21 June & 1.5 & 3.0 & 2.5 \\
\hline Total & 34.6 & 42.4 & 15.8 \\
\hline \multicolumn{4}{|c|}{1991} \\
\hline 16-3 Mar. & 11.4 & 0.0 & 0.0 \\
\hline 1-15 Apr. & 2.5 & 4.2 & 1.4 \\
\hline 16-30 Apr. & 9.9 & 4.8 & 0.5 \\
\hline 1-15 May & 5.6 & 6.3 & 3.7 \\
\hline 16-31 May & 6.9 & 12.7 & 2.6 \\
\hline 1-15 June & 8.1 & 7.4 & 3.9 \\
\hline 16-27 June & 6.4 & 6.0 & 4.9 \\
\hline Total & 50.8 & 41.4 & 17.0 \\
\hline \multicolumn{4}{|c|}{1992} \\
\hline 16-3 Mar. & 3.1 & 1.4 & 1.5 \\
\hline 1-15 Apr. & 2.8 & 5.9 & 2.4 \\
\hline 16-30 Apr. & 10.4 & 4.7 & I .5 \\
\hline 1-15 May & 3.3 & 5.2 & 2.6 \\
\hline 16-31 May & 1.5 & 7.4 & 3.6 \\
\hline 1-15 June & 4,8 & 8.8 & 4.3 \\
\hline 16-26 June & 4.1 & 6.0 & 2.5 \\
\hline Total & 25.9 & 39.4 & 18.4 \\
\hline
\end{tabular}


Table 2. Tomato marketable yield by fruit size as influenced by irrigation quantity.

\begin{tabular}{|c|c|c|c|c|}
\hline \multirow{2}{*}{$\begin{array}{l}\text { Irrigation } \\
\text { quantity (pan) }\end{array}$} & \multicolumn{4}{|c|}{ Marketable yield $\left(\mathrm{t} \cdot \mathrm{ha}^{-1}\right)^{2}$} \\
\hline & Ex-large & Large & Medium & Total \\
\hline \multicolumn{5}{|c|}{1990} \\
\hline 0 & 5.9 & 8.5 & 16.3 & 30.7 \\
\hline 0.25 & 15.8 & 15.0 & 17.8 & 48.6 \\
\hline 0.50 & 28.0 & 20.3 & 19.4 & 67.7 \\
\hline 0.75 & 36.5 & 21.7 & 21.1 & 79.3 \\
\hline 1.00 & 35.1 & 27.4 & 24.5 & 87.0 \\
\hline 0 vs. irrigation & $* *$ & $* *$ & $*$ & $* *$ \\
\hline Irrigation quantity & $Q^{* *}$ & $\mathrm{~L}^{* *}$ & $\mathrm{~L}^{*}$ & $\mathrm{~L}^{* *}$ \\
\hline \multicolumn{5}{|l|}{ Tensiometer } \\
\hline $10 \mathrm{cb}$ & 31.3 & 28.3 & 24.4 & 84.0 \\
\hline 0.75 pan vs. $10 \mathrm{cb}$ & $\mathrm{N} \mathrm{S}$ & $* *$ & $*$ & $\mathrm{~N} \mathrm{~S}$ \\
\hline \multicolumn{5}{|c|}{1991} \\
\hline 0 & 25.2 & 9.0 & 32.2 & 66.4 \\
\hline (). 25 & 25.9 & 7.4 & 24.4 & 57.7 \\
\hline 0.50 & 29.6 & 9.1 & 25.0 & 63,6 \\
\hline 0.75 & 28.5 & 9.4 & 25.1 & 63.0 \\
\hline 1.00 & 27.7 & 9.3 & 25.8 & 62.8 \\
\hline 0 vs. irrigation & $\mathrm{N} \mathrm{S}$ & $\mathrm{N} \mathrm{S}$ & $* *$ & $\mathrm{~N} \mathrm{~S}$ \\
\hline Irrigation quantity & N S & N S & N S & $\mathrm{N} \mathrm{S}$ \\
\hline \multicolumn{5}{|l|}{ Tensiometer } \\
\hline $10 \mathrm{cb}$ & 33.0 & 8.4 & 25.6 & 70.0 \\
\hline 0.75 pan vs. $10 \mathrm{cb}$ & $\mathrm{N} \mathrm{S}$ & $\mathrm{N} \mathrm{S}$ & $\mathrm{N} \mathrm{S}$ & $\mathrm{N} \mathrm{S}$ \\
\hline \multicolumn{5}{|c|}{1992} \\
\hline 0 & 15.2 & 8.2 & 19.8 & 43.2 \\
\hline 0.25 & 28.6 & 13.3 & 23.9 & 65.9 \\
\hline 0.50 & 36.8 & 13.8 & 22.2 & 72.7 \\
\hline 0.75 & 32.4 & 15.1 & 26.7 & 74.1 \\
\hline 1.00 & 31.9 & 13.5 & 24.9 & 70.3 \\
\hline 0 vs. irrigation & $* *$ & $* *$ & $* *$ & $* *$ \\
\hline Irrigation quantity & $Q^{* *}$ & $\mathrm{~N} \mathrm{~S}$ & $\mathrm{~N} \mathrm{~S}$ & Q* \\
\hline \multicolumn{5}{|l|}{ Tensiometer } \\
\hline $10 \mathrm{cb}$ & 35.7 & 12.2 & 25.5 & 73.4 \\
\hline 0.75 pan vs. $10 \mathrm{cb}$ & $\mathrm{N} \mathrm{S}$ & $\mathrm{N} \mathrm{S}$ & $\mathrm{N} \mathrm{S}$ & $\mathrm{N} \mathrm{S}$ \\
\hline
\end{tabular}

${ }^{2}$ Mean fruit weight for size categories were extra-large $205 \mathrm{~g}$, large $150 \mathrm{~g}$, and medium $115 \mathrm{~g}$.

'Mean separation of no irrigation vs. mean of pan irrigation quantities were nonsignificant (NS) or significant at $P=0.05$ (*) or 0.01

$(* *)$. Significant irrigation quantity effects were quadratic (Q) or linear (L).

$\mathrm{g} \cdot \mathrm{kg}^{-1}$. With the 10 -cb treatment, leaf $\mathrm{N}$ concentration was 48 $\mathrm{g} \cdot \mathrm{kg}^{-1}$ and between 50 and $46 \mathrm{~g} \cdot \mathrm{kg}^{-1}$ with 0.5 pan and 0.75 pan, respectively. Leaf $\mathrm{N}$ concentrations were similar at the end of the season (22 June) as at 1 June. In 1991 and 1992, leaf N concentrations were generally lower than in 1990 at similar sampling dates and with similar water quantities. In 1991, only leaf $\mathrm{N}$ values at the 2 June sampling were significantly affected by water quantity. Leaf $\mathrm{N}$ decreased linearly from $38.8 \mathrm{~g} \cdot \mathrm{kg}^{-1}$ with the application of 0 water to $32.9 \mathrm{~g} \cdot \mathrm{kg}^{-1}$ with the application of 1.0 pan. In 1992, leaf $\mathrm{N}$ concentrations were also decreased with increased water quantity applied at the 1 June and 1 July sampling. During the threeseason period, only at the 1 June 1992 leaf sampling did leaf $\mathrm{N}$ concentrations with the $10-\mathrm{cb}$ treatment differ from the leaf $\mathrm{N}$ concentration with the 0.75-pan treatment. On that date, the leaf $\mathrm{N}$ concentration was significantly higher with the $10-\mathrm{cb}$ than the 0.75-pan treatment.

Total water extractable $\mathrm{N}\left(\mathrm{NO}_{3}-\mathrm{N}+\mathrm{NH}_{4}-\mathrm{N}\right)$ values from soil samples taken during three seasons are shown in Fig. 2. At the 1 May 1990 sampling, soil $\mathrm{N}$ values were variable and not influenced by water quantities from 0.25 to 1.0 pan and averaged 31 $\mathrm{mg} \cdot \mathrm{kg}^{-1}$. With no irrigation where only the $40 \%$ preplant $\mathrm{N}$ and no fertigated $\mathrm{N}$ was applied, extractable soil $\mathrm{N}$ was significantly lower than with the former treatment and averaged $12 \mathrm{mg} \cdot \mathrm{kg}^{-1}$. With the 10-cb treatment, extractable soil $\mathrm{N}$ averaged $22 \mathrm{mg} \cdot \mathrm{kg}^{-1}$. At the later samplings on 1 June and 1 July, extractable soil $\mathrm{N}$ values were lower but not influenced by water quantity applied. In 1991 and 1992, soil samples with the 0-water treatment where 40\% $\mathrm{N}$ was applied preplant with weekly $\mathrm{N}$ applications with a 0.1 -pan application were higher in total $\mathrm{N}$ than all fertigated treatments with 0.25 to 1.0 pan. Soil $\mathrm{N}$ values with the $10-\mathrm{cb}$ treatment were similar to the average with all irrigation treatments.

The quantity of water to apply by pan evaporation to obtain maximum tomato production varies with soil type (Locascio et al., 1989), season (Olson and Rhoads, 1992), and rainfall. In these studies, maximum yields were consistently produced with water quantities of between 0.5 and 1.0 pan in dry years. In a season with $3.4 \mathrm{~cm}$ per week rainfall, no response was obtained to irrigation. In this study as in past studies on a coarse-textured sandy soil (Smajstrla and Locascio, 1990), maximum production was obtained with water equivalent to about 0.35 pan with the use of tensiometer scheduling of water at $10 \mathrm{cb}$. Timely irrigations to part of the root system have effectively provided water to tomatoes 


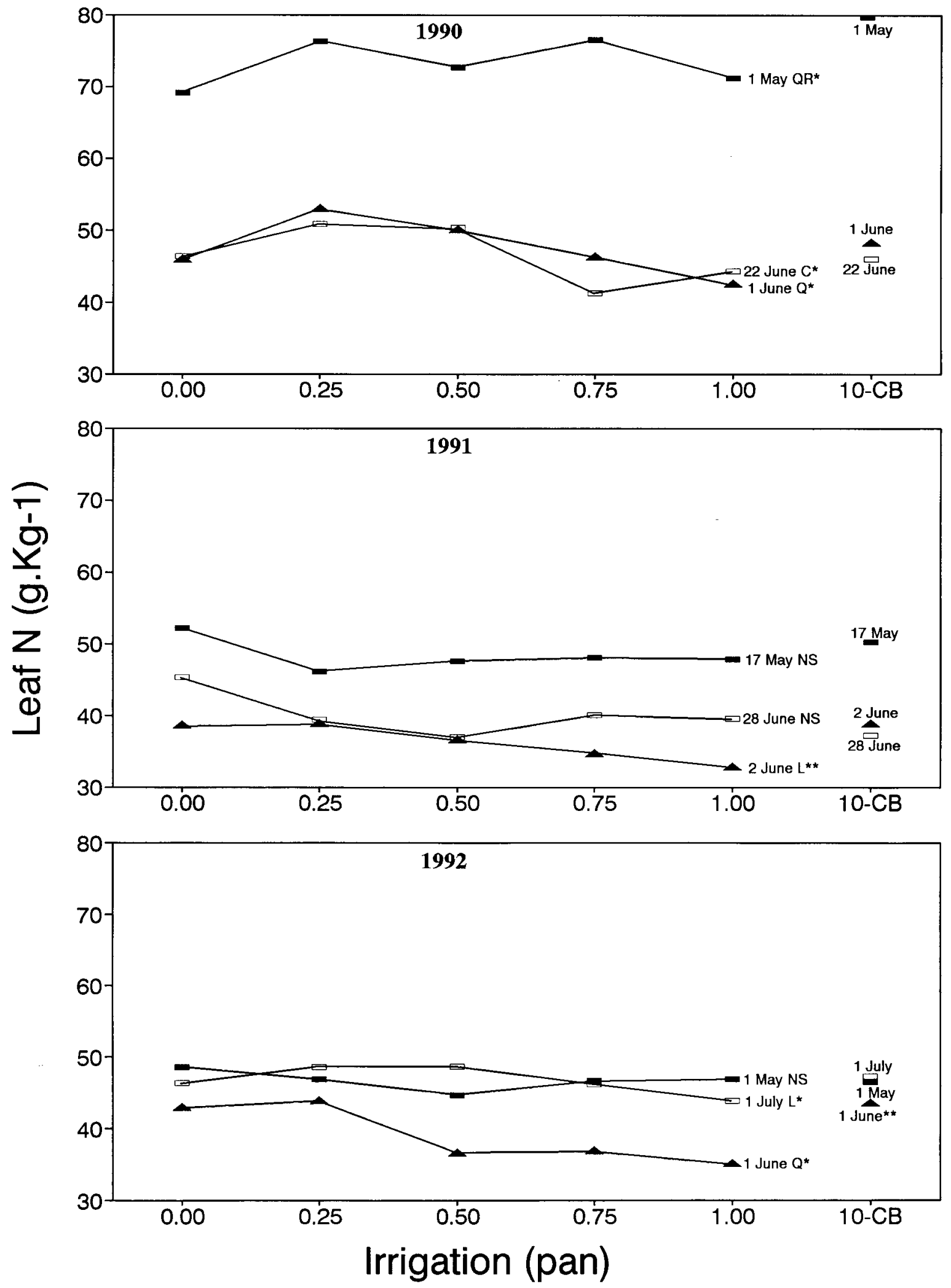

Fig. 1. The influence of irrigation treatment as a fraction of pan evaporation and water applied at $10 \mathrm{cb}$ on leaf tissue $\mathrm{N}$ concentration at three sample dates in each of 1990 to 1992. Effects of pan water quantity were significant at the $P=0.05\left({ }^{*}\right)$ and were quadratic (Q), cubic (C), or quartic (Qr) or nonsignificant (NS). Differences on the 1 June 1992 sampling with 0.75 pan and with $10 \mathrm{cb}$ was significant at the $P=0.01(* *)$.

(Tan et al., 1981). On finer-textured soils, tensiometer scheduling did not result in yields equivalent to that produced with 0.5 pan (Olson and Rhoads, 1992). In addition to an apparent reduction in water use, tensiometer scheduling can be more easily automated than the use of pan evaporation to schedule irrigation. Also, over-watering during rainfalls is less likely to occur with tensiometer than pan scheduling. 

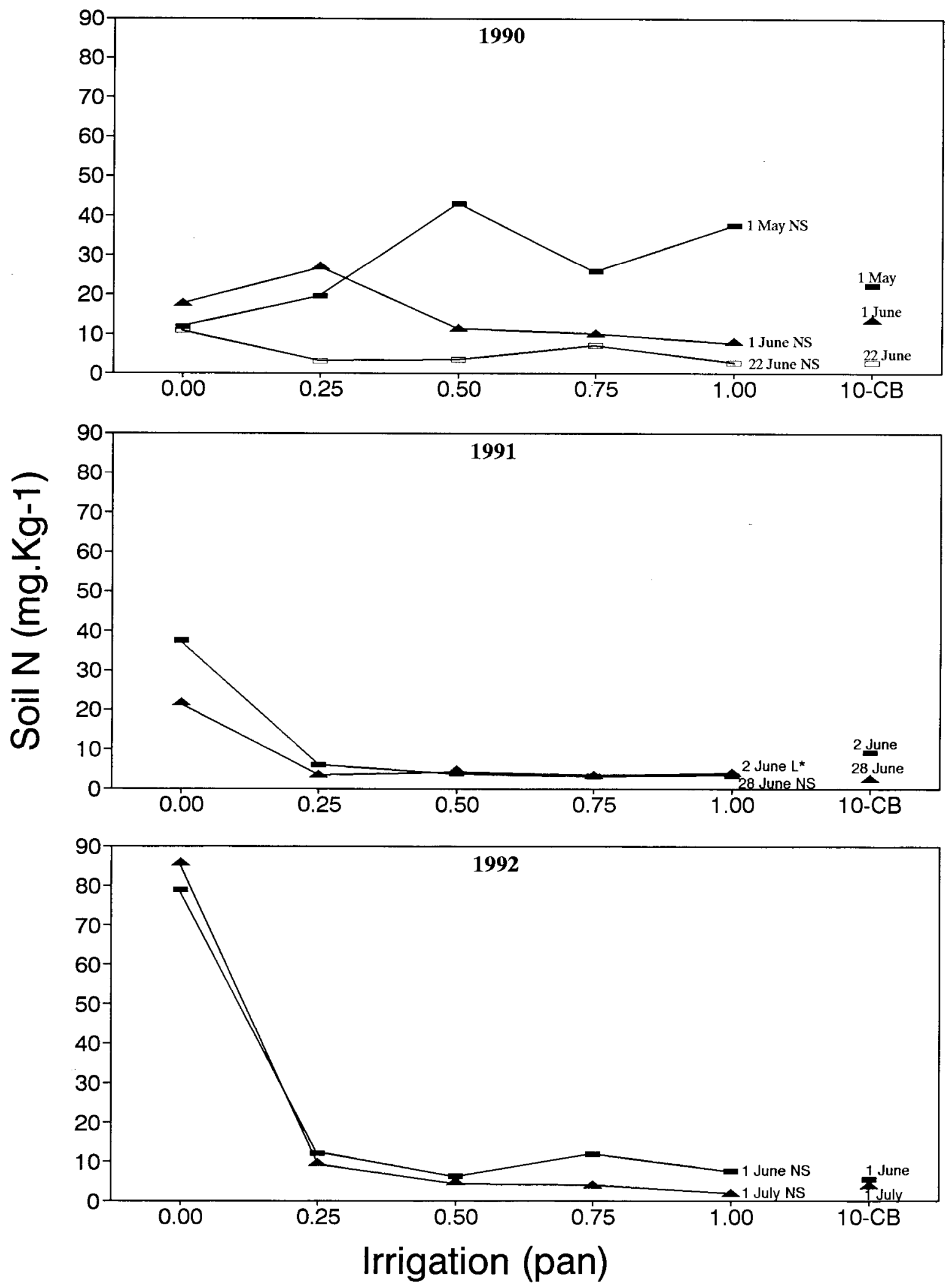

Fig. 2. The influence of irrigation treatment as a fraction of evaporation pan and water applied at $10 \mathrm{cb}$ on soil $\mathrm{N}$ (total of $\mathrm{NO}_{3}-\mathrm{N}$ and $\mathrm{NH}_{4}-\mathrm{N}$ ) at 0 to $15 \mathrm{~cm}$ at three sample dates in each of 1990 to 1992 . Effects of treatments were significant at $P=$ $0.05\left(^{*}\right)$ and was linear (L) or nonsignificant (NS).

\section{Literature Cited}

Dangler, J.M. and S.J. Locascio. 1990. Yield of trickle-irrigated tomatoes as affected by time of $\mathrm{N}$ and $\mathrm{K}$ application. J. Amer. Soc. Hort. Sci. 115:585-589.

Goldberg, D., B. Gornat, and Y. Bar. 1971. The distribution of roots, water, and minerals as a result of trickle irrigation. J. Amer. Soc. Hort. 
Sci. 96:645-648.

Hochmuth, G.J., S.J. Locascio, T.E. Crocker, C.D. Stanley, G.A. Clark, and L. R. Parsons. 1993. Impact of microirrigation on Florida horticulture. HortTechnology 3:223-229.

Locascio, S.J. and J.M. Myers. 1974. Tomato response to plug mix, mulch and irrigation method. Proc. Fla. State Hort. Soc. 87: 126-130.

Locascio, S.J., J.M. Myers, and J.G.A. Fiskell. 1982. Nitrogen application timing and source for drip irrigated tomatoes, p. 323-328. In: A. Scaife (cd.). Proc. 9th Intl. Plant Nutr. Colloq. Warwick Univ., U.K.

Locascio, S.J., S.M. Olson, and F.M. Rhoads. 1989. Water quantity and time of $\mathrm{N}$ and $\mathrm{K}$ application for trickle-irrigated tomatoes. J. Amer. Soc. Hort. Sci. 114:265-268.

Locascio, S.J. and A.G. Smajstrla. 1989. Drip irrigated tomato as affected by water quantity and $\mathrm{N}$ and $\mathrm{K}$ application timing. Proc. Fla. State Hort. Soc. 102:307-309.

Locascio, S.J. and A.G. Smajstrla. 1993. Pan evaporation scheduling for drip-irrigated tomato. Proc. Fla. State Hort. Soc. 106:216-218.
Olson, S.M. and F.M. Rhoads. 1992. Effect of water quantity on fall tomato production in North Florida. Proc. Fla. State Hort. Soc. 105:334336.

Persaud, N., S.J. Locascio, and C.M. Geraldson. 1976. Influence of fertilizer rate and placement and irrigation method on plant nutrient status, soil soluble salt and root distribution of mulched tomatoes. Proc. Soil Crop Sci. Soc. Fla. 36:121-125.

Prevatt, J.W., C.D. Stanley, and S.P. Kovach. 1984. An economic comparison of vegetable irrigation systems. Proc. Fla. State Hort. Soc. 97:213-215.

Smajstrla, A.G. and S.J. Locascio. 1990, Irrigation scheduling of dripirrigated tomato using tensiometers and pan evaporation. Proc. Fla. State Hort. Soc. 103:88-91.

Tan, C. S., A. Cornelisse, and B.R. Buttery. 1981. Transpiration, stomata] conductance, and photosynthesis of tomato plants with various proportions of root system supplied with water. J. Amer. Soc. Hort. Sci. 106:147-151. 